\title{
Od orzeczenia o potrzebie kształcenia specjalnego do indywidualnego programu edukacyjno-terapeutycznego
}

\begin{abstract}
Mariusz Wielebski, Od orzeczenia o potrzebie ksztatcenia specjalnego do indywidualnego programu edukacyjno-terapeutycznego [From the decision on special education eligibility to an individual educational and therapeutic plan]. Interdyscyplinarne Konteksty Pedagogiki Specjalnej, nr 22, Poznań 2018. Pp. 339-354. Adam Mickiewicz University Press. ISSN 2300-391X. DOI: https://doi.org/10.14746/ikps.2018.22.19

In my article I would like to show the complicated way from the decision about special education to individual educational and therapeutic plan. I am going to show how government statements are sometimes hard and complicated for parents, teachers and other specialists, who are looking after the children with special educational needs. I try to show everyday life in my job - teacher, specialist of pedagogical therapy. I hope my article will help and change our reality.
\end{abstract}

KEY WORDS: decision, disability, special educational needs, special education, individual educational and therapeutic plan (IETP)

\section{Wprowadzenie}

Edukacja uczniów z orzeczeniem o potrzebie kształcenia specjalnego w polskim systemie oświaty - a więc ogólnie mówiąc kształcenie specjalne - mogą być obecnie realizowane zarówno w szkołach, przedszkolach czy placówkach specjalnych, jak i inte- 
gracyjnych oraz $\mathrm{w}$ ramach edukacji włączającej ${ }^{1}$. Tak zróżnicowana ścieżka oznacza jednak analizę funkcjonowania różnych elementów tego systemu, by faktycznie można było mówić o wysokiej jakości kształcenia - bez względu na rodzaj wybranej szkoły. Edukacja włączająca w szkołach ogólnodostępnych funkcjonuje bowiem w Polsce zaledwie od kilku lat, stąd ciągle jeszcze pojawia się szereg pytań i wątpliwości, jak skutecznie wspierać ucznia. Kiedy do szkoły ogólnodostępnej przychodzi uczeń posiadający orzeczenie o potrzebie kształcenia specjalnego, zespół uczących go nauczycieli, w oparciu o zapisy rozporządzenia Ministra Edukacji Narodowej w sprawie warunków organizowania kształcenia, wychowania i opieki dla dzieci i młodzieży niepełnosprawnych, niedostosowanych społecznie i zagrożonych niedostosowaniem społecznym ${ }^{2}$, musi opracować Indywidualny Program Edukacyjno-Terapeutyczny (IPET). To trudne zadanie dla nauczycieli szkół ogólnodostępnych, niebędących pedagogami specjalnymi. Celem mojego artykułu jest przedstawienie problemów pojawiających się od momentu złożenia przez rodzica lub prawnego opiekuna dziecka wniosku o wydanie orzeczenia o potrzebie kształcenia specjalnego do napisania, IPETu, wraz z przykładami dobrych i złych praktyk oraz moich doświadczeń z codziennego życia poradni psychologiczno-pedagogicznej związanych z procesem tworzenia tych dokumentów.

\section{IPET - Indywidualny Program Edukacyjno-Terapeutyczny}

W dniu 1 września 2015 r.weszło w życie Rozporządzenie Ministra Edukacji Narodowej z dnia 24 lipca 2015 r. w sprawie warun-

${ }^{1}$ I. Chrzanowska, Pedagogika specjalna. Od tradycji do wspótczesności, Oficyna Wydawnicza „Impuls”, Kraków 2015; G. Szumski, Integracyjne kształcenie niepetnosprawnych, WydawnictwoAkademii Pedagogiki Specjalnej i Państwowe Wydawnictwo Naukowe, Warszawa 2013.

2 Rozporzadzenie Ministra Edukacji Narodowej z dnia 9 sierpnia 2017 r. w sprawie warunków organizowania kształcenia, wychowania i opieki dla dzieci i młodzieży niepetnosprawnych, niedostosowanych społecznie $i$ zagrożonych niedostosowaniem społecznym (Dz.U. z dnia 24 sierpnia 2017 r. poz. 1578). 
ków organizowania kształcenia, wychowania i opieki dla dzieci i młodzieży niepełnosprawnych, niedostosowanych społecznie i zagrożonych niedostosowaniem społecznym ${ }^{3}$. Przedtem funkcjonowały dwa osobne rozporządzenia dotyczące edukacji tych uczniów: jedno w szkołach ogólnodostępnych lub integracyjnych, drugie w szkołach specjalnych - Rozporządzenie z roku 2015 wprowadza już wspólne rozwiązania. Określa ono między innymi organizację warunków kształcenia specjalnego oraz opisuje tworzenie Indywidualnych Programów Edukacyjno-Terapeutycznych (IPET). Ośrodek Rozwoju Edukacji w Warszawie opracował materiał dydaktyczny, w którym znajdujemy zarówno podstawy prawne, jak również praktyczne porady dotyczące tworzenia IPET-ów ${ }^{4}$. W Banku Dobrych Praktyk Wydziału Specjalnych Potrzeb Edukacyjnych ORE dostępne są przykładowe IPET-y dla uczniów z różnego rodzaju problemami rozwojowymi ${ }^{5}$. Są to bardzo pożyteczne materiały, ponieważ nauczyciele szkół ogólnodostępnych ciągle szukają wskazówek metodycznych. Poza tym prezentacja różnych rozwiązań jest niezwykle wartościowa, gdyż poza elementami wynikającymi z przywołanego Rozporządzenia, nie funkcjonują w polskim systemie oświaty żadne obowiązujące formalne wzorce czy kwestionariusze IPET-ów. Każda szkoła może wypracować dogodny dla siebie wzorzec, jeśli tylko odpowiada on kryteriom zawartym w Rozporządzeniu. Pozostawia to dużą dowolność, ale zwiększa też zakres odpowiedzialności placówki i samych nauczycieli. Dlatego tak ważne jest zrozumienie zasad tworzenia IPET-ów, by wyko-

${ }^{3}$ Rozporzadzenie Ministra Edukacji Narodowej z dnia 24 lipca 2015 r. w sprawie warunków organizowania ksztatcenia, wychowania $i$ opieki dla dzieci $i$ młodzieży niepetnosprawnych, niedostosowanych społecznie $i$ zagrożonych niedostosowaniem spotecznym Dz.U. z dnia 7.08.2015, poz. 1113.

${ }^{4}$ Rafał-Łuniewska J., Zmiany warunków organizowania kształcenia specjalnego, ORE Warszawa 2015: https://www.ore.edu.pl/component/phocadownload/category/ 77-inne?download=3450:zmiany-warunkow-organizowania-ksztalcenia-specjalnegow-edukacji-ogolnodostepnej [dostęp: 10.06.2017].

${ }^{5}$ Zob. Bank dobrych praktyk, Portal internetowy Ośrodka Rozwoju Edukacji MEN, [online] https://www.ore.edu.pl/programy-i-projekty-69647/bank-dobrychpraktyk-82894/dobre-praktyki [dostęp: 10.06.2017]. 
rzystać je jak najlepiej do własnych potrzeb nauczycieli i specjalistów pracujących $\mathrm{z}$ dzieckiem niepełnosprawnym w szkole. $\mathrm{W}$ dniu 1 września 2017 r. weszły w życie zapisy nowego Rozporządzenia MEN w sprawie warunków organizowania kształcenia, wychowania i opieki dla dzieci i młodzieży niepełnosprawnych, niedostosowanych społecznie i zagrożonych niedostosowaniem społecznym. Jego zapisy dookreślają i porządkują sposób organizacji kształcenia specjalnego w szkołach różnego typu i placówkach ${ }^{6}$.

Tworzenie IPET-u to planowanie wspierania ucznia z orzeczeniem o potrzebie kształcenia specjalnego. To trudne zadanie dla placówek ogólnodostępnych, w których nie zatrudnia się pedagogów specjalnych. Przygotowanie nauczycieli szkół ogólnodostępnych pozostawia $\mathrm{w}$ tym zakresie wiele do życzenia7 $\mathrm{i}$ trudno mieć o to do nich pretensje. Mimo wprowadzenia inkluzji do polskich szkół, nie wypracowano do tej pory obowiązkowych standardów kształcenia pedagogów w zakresie pedagogiki specjalnej. Dorota Podgórska-Jachnik pisze:

Trudno osiągnąć stan gotowości i otwarcia szkoły [ogólnodostępnej dop. M.W.] na potrzeby dziecka z każdą niepełnosprawnością, bazując [jedynie - dop. M.W.] na dodatkowym specjalistycznym przygotowaniu każdego nauczyciela. To po prostu niemożliwe. Szkoły będą próbowały kompensować te niedostatki przerzucając ciężar zapewnienia fachowości na barki nauczyciela wpierającego, nauczyciela i/lub psychologa doradcy, pedagoga szkolnego $\mathrm{z}$ odpowiednim przygotowaniem, docelowo - zgodnie $\mathrm{z}$ założeniami reformy systemu edukacji

${ }^{6}$ Rozporządzenie Ministra Edukacji Narodowej z dnia 9 sierpnia 2017 r. w sprawie warunków organizowania kształcenia, wychowania i opieki dla dzieci i młodzieży niepełnosprawnych, niedostosowanych społecznie i zagrożonych niedostosowaniem społecznym (Dz.U. z dnia 24 sierpnia 2017 r. poz. 1578).

${ }_{7}$ B. Jachimczak, Special Pedagogue in a mainstream school - a possibilities and limitation, „Studia Edukacyjne” Nr 7, s. 233-239 Poznań 2008; B. Jachimczak, Przygotowanie nauczycieli wychowania przedszkolnego do realizacji wybranych zadań z zakresu pomocy psychologiczno-pedagogicznej, „Studia Edukacyjne”, Poznań 2012, Nr 21, s. 163-176; Plichta P. Przygotowanie nauczycieli do edukacji wtaczającej - kontekst europejski, [w:] Dobre praktyki pedagogiczne szansa innowacyjnej edukacji, red. D. Podgórska-Jachnik, Wydawnictwo Wyższej Szkoły Pedagogicznej, Łódź 2012 s. 101-114, i inne. 
uruchamiającej w oświacie ruch inkluzyjny - na cały szkolny zespół do spraw specjalnych potrzeb edukacyjnych ${ }^{8}$.

W skład zespołu ds. pracy z uczniem o Specjalne Potrzeby Edukacyjne wchodzą wszyscy nauczyciele i specjaliści pracujący z dzieckiem, bez względu na to ile czasu z nim przebywają. Każdy z nich powinien, uwzględniając specyfikę nauczanego przedmiotu, uczestniczyć w tworzeniu programu. Przy konstruowaniu IPET-u należy zwrócić uwagę na jego strukturę. Logika tworzenia IPET-u obejmuje trzy uzupełniające się poziomy:

I poziom - diagnostyczny; tu istotne są: wnikliwa analiza orzeczenia (diagnoza, zalecenia, uzasadnienie), wielospecjalistyczna ocena poziomu funkcjonowania dziecka (badania specjalistyczne w przedszkolu, szkole i poradni - psychologiczne, logopedyczne i inne, rozpoznanie przeprowadzone przez nauczycieli, wywiad $z$ rodzicami), specjalne potrzeby edukacyjne dziecka/ucznia (określenie jego potrzeb);

II poziom - programowy; to zasadniczy proces tworzenia IPET-u, który powinien zawierać przede wszystkim: cele terapeutyczne - zasady pracy z dzieckiem, cele edukacyjne - wynikające z podstawy programowej, czyli to określenie procedury osiągania celów, dostosowania otoczenia i wymagań edukacyjnych, rodzajów pomocy i wsparcia;

III poziom - praktyczny; obejmuje konkretne działania podejmowane w celu realizacji programu, czyli: wspieranie, zajęcia (obowiązkowe, dodatkowe, nadobowiązkowe) ${ }^{9}$. Poziom praktyczny zawiera także bieżącą ocenę efektów pracy, oczekiwane osiągnięcia dziecka oraz ewaluację programu ${ }^{10}$.

8 D. Podgórska-Jachnik, Uwarunkowania i perspektywy edukacji włączającej osób z uszkodzonym stuchem, [w:] Edukacja niestyszacych, red. E. Twardowska, M. Kowalska, Wydawnictwo Polskiego Związku Głuchych w Łodzi, Łódź 2011, s. 28-29.

${ }_{9}$ Podniesienie efektywności kształcenia uczniów ze specjalnymi potrzebami edukacyjnymi, Materiały szkoleniowe Ministerstwa Edukacji Narodowej, Część II, Warszawa 2010, s. 6-27.

10 Łuniewska-Rafał J., Zmiany warunków ksztatcenia specjalnego, Ośrodek Rozwoju Edukacji, Warszawa 2015, s. 4. 
W broszurze ORE opisane są role i zadania dyrektora szkoły oraz zespołu nauczycieli uczących danego ucznia i jego rodziców. Pojawia się w nim również pojęcie diagnozy funkcjonalnej i wyjaśnienie co na nią się składa. To istotne, gdyż programu pracy z uczniem ze specjalnymi potrzebami edukacyjnymi nie można napisać, kierując się jedynie etykietą diagnozy nozologicznej. Przed napisaniem Indywidualnego Programu-Terapeutycznego bardzo ważna jest obserwacja dziecka, prowadzona przez poszczególnych nauczycieli uczących lub pracujących z nim.

Warto zwrócić jeszcze uwage na wynikające z Rozporządzenia sformułowanie „wielospecjalistyczna ocena poziomu funkcjonowania ucznia / dziecka” (WOPFU). Moim zdaniem to najważniejszy element podstawy konstruowania Indywidualnego Programu Edukacyjno-Terapeutycznego. Na tę właśnie ocenę składają się: z jednej strony - wszystkie zaświadczenia wydane przez lekarzy specjalistów, ewentualne karty informacyjne, wypisy ze szpitali, opinie specjalistów opiekujących się dzieckiem, orzeczenie o potrzebie kształcenia specjalnego, z drugiej - obserwacje nauczycieli i rodziców, jak również stosowna do potrzeb diagnoza funkcjonalna przeprowadzona w szkole. Podkreślam szczególnie ten drugi element. Jeżeli połączymy te wszystkie źródła informacji: diagnozy lekarzy, opinie pedagogów, psychologów i innych specjalistów z opinią nauczycieli i rodziców - dopiero wtedy będziemy mieli pełny obraz dziecka, który zwiększy szansę opracowania najlepszego dla niego IPET-u. Należy podkreślić, że wielospecjalistyczną ocenę poziomu funkcjonowania ucznia (WOPFU) na mocy cytowanego Rozporządzenia MEN z dnia 9 sierpnia 2017 r. przeprowadza zespół nauczycieli uczących danego ucznia co najmniej dwa razy $\mathrm{w}$ roku11. Optymalnym rozwiązaniem byłoby, gdyby pierwsza ocena na początku roku stanowiła diagnozę wyjściową do IPET-u, a druga służyła ocenie efektów pracy (ewaluacji) i ewentualnej korekcie IPET-u na kolejny rok szkolny/etap kształcenia. W ten sposób tworzy się pewien logiczny cykl, odzwierciedlający procesualny charakter działań dostosowawczych edukację do specjalnych potrzeb ucznia:

11 Rozporządzenie Ministra Edukacji Narodowej z dnia 9 sierpnia 2017 r. w sprawie warunków organizowania kształcenia... 


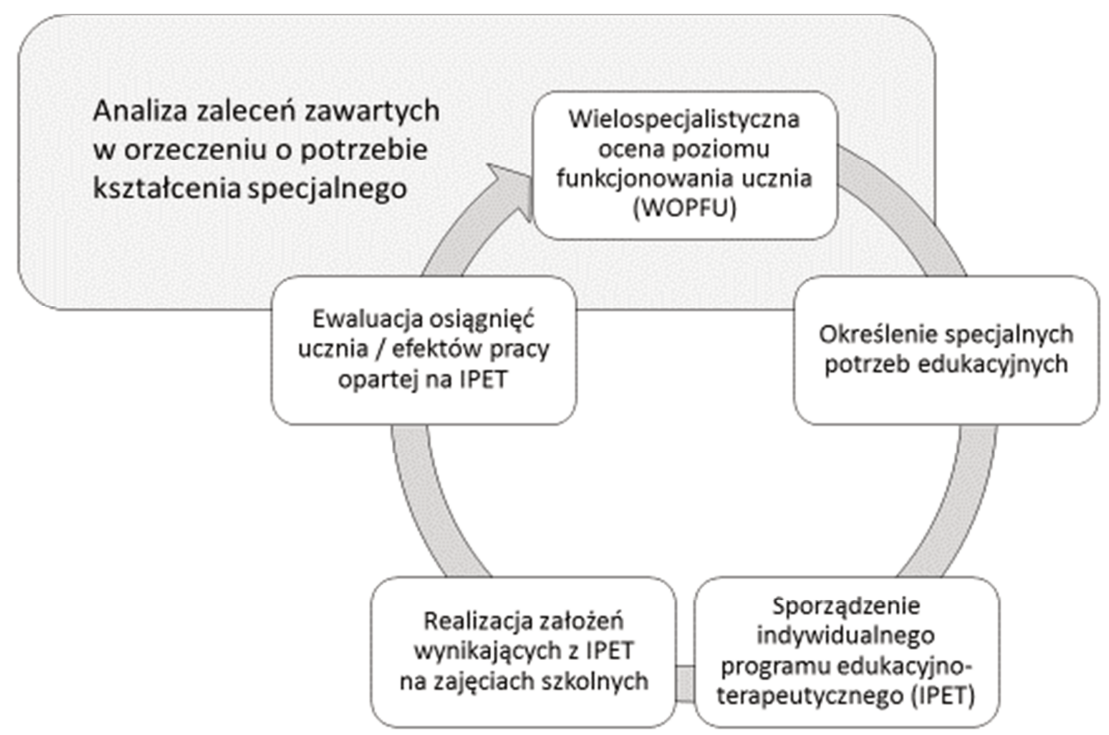

Rys. 1. Proces dostosowywania edukacji szkolnej do specjalnych potrzeb ucznia, $\mathrm{z}$ uwzględnieniem tworzenia WOPFU i IPET

Źródło: opracowanie własne, z wykorzystaniem pracy I. Skibskiej i M. Warchał12

Arkusz WOPFU13 zawiera w formie tabelarycznej szczegółowe pytania wraz z komentarzami tak, aby każdy zespół przygotował najlepszą ocenę podopiecznego. W posiedzeniach zespołu może wziąć udział rodzic lub prawny opiekun dziecka, którego szkoła ma obowiązek powiadomić o terminie spotkania zespołu. Częstym błędem nauczycieli jest zapoznawanie się z treścią orzeczenia dopiero na posiedzeniu zespołu. Uważam, że każda szkoła powinna opracować system - zbiór procedur, które określą drogę od złożenia

12 I. Skibska, M. Warchał, Edukacja inkluzyjna dziecka niepetnosprawnego w szkole ogólnodostępnej a integracja społeczna, [w:] Edukacja Jutra w kontekście wyzwań współczesności, red. K. Denek i in, Oficyna Wydawnicza „Humanitas”, Sosnowiec 2011, s. 378 .

${ }^{13}$ R. Cybulska, Uczeń ze specjalnymi potrzebami edukacyjnymi w systemie edukacji w świetle nowych przepisów prawa oświatowego, ORE, Warszawa 2017. 
orzeczenia przez rodzica do pierwszego spotkania zespołu. Dobrą praktyką jest przedstawienie rodzicowi propozycji pracy $\mathrm{z}$ dzieckiem zarówno w zakresie poszczególnych przedmiotów nauczania, jak również konkretny rodzaj i liczba zajęć specjalistycznych, np. logopedycznych z podaniem liczby godzin i dni, w których zajęcia te będą realizowane.

Jeżeli solidnie przeprowadzimy wielospecjalistyczną ocenę poziomu funkcjonowania ucznia i w każdej następnej WOPFU właściwie ocenimy naszego podopiecznego, nie powinniśmy mieć większego problemu $\mathrm{z}$ napisaniem odpowiedniego dla naszego ucznia IPET-u i dalszej ewaluacji uzyskanych efektów pracy.

\section{Budowa Indywidualnego Programu Edukacyjno-Terapeutycznego}

Ponieważ głównym celem IPET-u jest pomoc dziecku wymagającemu specjalnej opieki i wsparcia edukacyjnego, treści zawarte $\mathrm{w}$ programie powinny mieć przede wszystkim wymiar praktyczny, tzn. mogący w sposób prosty przełożyć się na konkretne działania o charakterze terapeutycznym. W procesie tworzenia IPET-u bardzo pomocne okazują się opracowane przez specjalistów szablony dokumentacji, w których sposób uporządkowany, przejrzysty jesteśmy w stanie opisać jego najważniejsze elementy.

Jak już wspomniano, mogą być różne wzorce IPET-ów. Ze względu na brak formalnego szablonu, warto spojrzeć na tę kwestię alternatywnie - i z taką intencją chciałbym przedstawić to dwie odmienne propozycje, które z perspektywy własnej praktyki mogę polecić innym nauczycielom. W moim przekonaniu na uwagę zasługuje propozycja opracowana przez Romanę Cybulską i Barbarę Łaską ${ }^{14}$ zaś drugą wartościową propozycją dokumentacji IPET-u

${ }^{14}$ R. Cybulska, B.Łaska, Ośrodek Rozwoju Edukacji, Wydział Specjalnych Potrzeb Edukacyjnych, aktualności, https://www.ore.edu.pl/o-nas/wydzialy/specjal nych-potrzeb-edukacyjnych/7878-kszta\%C5\%82cenie-specjalne-\%E2\%80\%93-propo zycje-arkuszy [dostęp: 8.11.2017]. 
jest formularz opracowany przez Monikę Gołubiew-Konieczną 15. W tym drugim przypadku autorka podkreśla, jak ważnym aspektem na etapie obserwacji i diagnozy dziecka jest znalezienie mocnych i słabych stron dziecka/ucznia. Wystarczy, że znajdziemy chociaż jeden obszar, jedną czynność dobrze wykonywaną przez dziecko/ucznia - jego mocną stronę, aby właśnie na niej oprzeć całą naszą pracę terapeutyczną.

Obie propozycje IPET-ów różnią się na pierwszy rzut oka, choć obie respektują wszystkie zalecenia Rozporządzenia MEN z dnia 9 sierpnia 2017 r. W każdym z przedstawionych wzorów widzimy elementy stałe. Należą do nich: metryczka (imię/imiona i nazwisko dziecka, data napisania dokumentu, okres realizacji, kto wydał orzeczenie). Pozostałe stałe elementy wynikające $\mathrm{z}$ cytowanego Rozporządzenia MEN: zintegrowane działania nauczycieli i specjalistów prowadzących zajęcia $\mathrm{z}$ dzieckiem; formy i okres udzielania dziecku lub uczniowi pomocy psychologiczno-pedagogicznej oraz wymiar godzin, w którym poszczególne formy pomocy będą realizowane; zakres współpracy nauczycieli i specjalistów z rodzicami dziecka lub ucznia $\mathrm{w}$ realizacji przez przedszkole lub oddział przedszkolny, szkołę lub ośrodek zadań zawartych w orzeczeniu o potrzebie kształcenia specjalnego (inne zalecenia zawarte $\mathrm{w}$ orzeczeniu, sprzęt specjalistyczny, inna pomoc); w zależności od potrzeb zakres współdziałania z poradniami psychologiczno-pedagogicznymi; okresowa wielospecjalistyczna ocena poziomu funkcjonowania dziecka/ucznia, uwzględniająca ocenę efektywności pomocy psychologiczno-pedagogicznej udzielanej uczniowi (jak już wspomniano, nie rzadziej niż raz w roku szkolnym).

Formularz Romany Cybulskiej i Barbary Łaskiej można polecić przede wszystkim osobom, które lubią wszelkiego rodzaju zestawienia tabelaryczne. Znam wielu takich nauczycieli. Twierdzą, że tabela lepiej porządkuje dokumentację, przez co może być łatwiej-

${ }^{15}$ Monika Gołubiew-Konieczna, dyrektor Poradni - dyrektor Poradni Psychologiczno-Pedagogicznej nr 7 w Gdańsku, psycholog, oligofrenopedagog, autorka wielu publikacji z zakresu pracy z uczniem ze specjalnymi potrzebami edukacyjnymi. 
sza w użyciu. Podział na wiersze i kolumny nie pozwala na rozproszenie danych oraz daje poczucie, że o niczym nie zapomnimy. Przeciwnicy tego podejścia uważają, że tabela ogranicza - narzuca określony styl i wymusza wcześniej wskazane działania, zakłada działania stereotypowe i nie pozwala na innowacyjność. Stąd druga propozycja IPET-u autorstwa Moniki Gołubiew-Koniecznej daje większą dowolność, ale nie zawiera szczegółowych przykładów konkretnych treści, które mogłyby być wpisane w poszczególne części IPET-u. U doradców metodycznych WODN-ów czy w internecie znajdziemy wiele wzorów IPET-ów (niestety, nie wszystkie wykonane prawidłowo). Jestem przekonany, że każdy zespół nauczycieli tworzących program wybierze coś dla siebie. Oczywiście ani jeden, ani drugi wzór z wybranych przeze mnie do prezentacji w niniejszym artykule nie jest tworem stałym. Można te wzory dowolnie modyfikować i/lub stworzyć własny. Najważniejsze, aby nie zapomnieć o elementach wynikających $\mathrm{z}$ Rozporządzenia. Radzę, aby wybrać jeden zunifikowany wzór dla danej szkoły, zaakceptowany przez jej nauczycieli. Nie jest dobrą praktyką tworzenie wielu wzorów, ale bardzo dobrze jest stworzyć własny wzór uwzględniający specyfikę danej szkoły. IPET jest narzędziem pracy i jako takie musi znaleźć akceptację osób, które z niego korzystają na co dzień. Warto więc omówić struktury IPET-u, uczynić przedmiotem debaty samokształceniowej określonej Rady Pedagogicznej i nie rezygnować z jego modyfikacji, jeśli zajdzie taka potrzeba. Powinien być to normalny proces doskonalenia warsztatu pracy pracowników szkoły.

Podstawowym dokumentem, który pozwala na dopasowanie IPET-u do potrzeb ucznia, jest orzeczenie o potrzebie kształcenia specjalnego, uzyskane z publicznej poradni psychologiczno-pedagogicznej. Ponieważ w orzeczeniu określony jest czas jego obowiązywania - najczęściej wydawane jest ono na etap edukacyjny - na taki sam okres opracowujemy IPET. W orzeczeniu można znaleźć elementy niezbędne $\mathrm{w}$ planowaniu wsparcia dla ucznia oraz w konkretnych działaniach dostosowawczych i rewalidacyjnych szkoły: to diagnoza, zalecenia i ich merytoryczne uzasadnienie. 
Tylko zaplanowane działania szkoły, które są zgodne z treścią zawartych $\mathrm{w}$ orzeczeniu zaleceń, mogą zostać sfinansowane przez organ prowadzący. Jest to więc zarówno wskazanie kierunku, jak i rama dla działań dostosowawczo-rewalidacyjnych.

Diagnoza zawarta $\mathrm{w}$ orzeczeniu zawiera zarówno informacje o problemach, jak i o możliwościach rozwojowych i potencjale dziecka. Powinno to znaleźć swoje odzwierciedlenie w Idnywidualnym Programie Edukacyjno-Terapeutycznym. Należy przyznać, że zdarza się, iż szkoły skarżą się czasem na źle sporządzane orzeczenia. Może się tak zdarzyć, choć barierą może okazać się także nieumiejętność ich odczytywania i interpretacji przez nauczycieli. To obszar wspólnej troski i od dobrej współpracy szkoły i poradni zależy, czy język komunikacji jest to doskonalony. Taką szansę daje oparcie orzeczenia na diagnostyce funkcjonalnej ICF (ang. International Classificaton of Functioning, Disability and Health - Międzynarodowej Klasyfikacji Funkcjonowania, Niepełnosprawności i Zdrowia). Ministerstwo Edukacji Narodowej opracowywało nowe wzory orzeczeń opartych właśnie o tę nową klasyfikację funkcjonalną Światowej Organizacji Zdrowia - dokładnie na jej wersji dla dzieci i młodzieży ICF-CY (ang. International Classificaton of Functioning, Disability and Health - Children and Youth) ${ }^{16}$ do IPET-u. W dniu 7 września 2017 r. MEN wydało nowe rozporządzenie w sprawie opinii i orzeczeń, w którym zamieszcza nowe wzory druków i nowe zasady ich wydawania ${ }^{17}$. Ten akt prawny wskazuje na możliwość wystąpienia przewodniczącego zespołu orzekającego do dyrektora szkoły/placówki o wydanie opinii, która jest niezbędna do wydania ww. orzeczenia. Przygotowany przez szkołę/placówkę druk całkowicie oparty jest na diagnozie funkcjonalnej i mocnych stronach ucznia ${ }^{18}$.

16 Ibidem.

17 Rozporządzenie Ministra Edukacji Narodowej z dnia 7 września 2017 r. w sprawie orzeczeń i opinii wydawanych przez zespoły orzekające działające w publicznych poradniach psychologiczno-pedagogicznych (Dz.U. 2017, poz. 1743).

${ }^{18} \mathrm{Na}$ podstawie § 7.1 Rozporządzenia Ministerstwa Edukacji Narodowej z dnia 7 września 2017 r., w sprawie orzeczeń i opinii wydawanych... 
Z poprawnie opracowanego IPET-u można uzyskać m.in. wiedzę: o podstawie programowej odpowiedniej dla naszego ucznia, o rozpoznanych u niego chorobach somatycznych, o liczbie i rodzaju sugerowanych zajęć specjalistycznych, na temat tego, jak uczeń funkcjonuje $\mathrm{w}$ grupie, jakie posiada kompetencje społeczne, jak rozwinięte są jego możliwości psychiczne i fizyczne, jak funkcjonuje w stosunku do swojego wieku metrykalnego, jaki posiada potencjał, a więc możliwości i mocne strony. $W$ razie wątpliwości można skontaktować się z poradnią $\mathrm{w}$ celu interpretacji lub uzupełnienia obrazu diagnostycznego i warto to robić, by uniknąć pomyłek, które niestety odbijają się przede wszystkim na uczniu.

Zawarte $\mathrm{w}$ orzeczeniu zalecenia konkretyzują wizję wsparcia dla ucznia, wypracowaną w poradni. Dotyczą one w szczególności: sugerowanej najkorzystniejszej dla dziecka formy kształcenia; form stymulacji, zajęć rewalidacyjnych, terapii, usprawniania, rozwijania potencjalnych możliwości i mocnych stron dziecka oraz innych form pomocy psychologiczno-pedagogicznej; warunków realizacji potrzeb edukacyjnych ${ }^{19}$. To $\mathrm{w}$ zależności od rodzaju niepełnosprawności na podstawie specjalistycznej diagnozy określa się optymalny dla danego ucznia poziom adaptacji oraz wynikający z niego zakres rewalidacji ${ }^{20}$. Jest to bezpośrednia podpowiedź, jak sprofilować zajęcia rewalidacji indywidualnej dla konkretnego dziecka. Rozporządzenie podaje jako przykładowe formy rewalidacji indywidualnej, np. naukę orientacji przestrzennej i poruszania się, naukę alfabetu Braille'a lub innych alternatywnych metod komunikacji (uczniowie niewidomi), naukę języka migowego czy innych wspomagających lub alternatywnych form komunikacji (uczniowie $\mathrm{z}$ uszkodzonym słuchem lub afazją), rozwijanie umiejętności społecznych, w tym komunikacyjnych (uczniowie z autyzmem,

19 Dudzińska A., Niedźwiedzka A. (2016), Najczęstsze pytania dotyczące ksztatcenia specjalnego informator dla rodziców, s. 11, [online] http://niegrzecznedzieci.org.pl/wpcontent/uploads/2016/01/WszystkoJasne-Raport-Najcze\% CC\% A8stsze-PytaniaDotycza \% CC\%A8ce-Kszta\% C5\%82cenia-Specjalnego.pdf [dostęp: 20.05.2017].

20 Ibidem, s. 67. 
w tym z zespołem Aspergera) ${ }^{21}$, lecz mogą to być również zajęcia ukierunkowane na zdobycie innych kompetencji o charakterze rewalidacyjnym. Uczniom z niepełnosprawnością intelektualną zaleca się zajęcia rozwijające procesy poznawcze. Jeśli jest taka potrzeba, poradnia może także zalecić niezależne od zajęć rewalidacyjnych zajęcia specjalistyczne, stanowiące element pomocy psychologicznopedagogicznej uczniom w polskim systemie oświatowym. Wszystkie zalecenia poradni powinny być uzasadnione - to również obligatoryjna część orzeczenia, przydatna dla nauczycieli opracowujących IPET.

Choć orzeczenie o potrzebie kształcenia specjalnego jest podstawowym dokumentem do tworzenia IPET- $u$, to jednak nie chodzi tu o mechaniczne przeniesienie treści jednego dokumentu do drugiego, tylko o uruchomienie procesu heurystycznych poszukiwań rozwiązań o charakterze strategicznym. Dlatego proponuję, aby przed opracowaniem IPET-u każdy tworzący go nauczyciel czy zespół zadał sobie cztery ważne i proste pytania odnoszące się do ucznia:

- Jaki jest (kluczowy) problem ucznia?

- Dlaczego problem się pojawił?

- Jak można uczniowi pomóc?

- Dlaczego wybieramy właśnie taki sposób?

Jeżeli tworzenie IPET-u poprzedzi uważna obserwacja i dobra diagnoza dziecka, nie powinno być problemu z odpowiedzią na powyższe pytania. Kiedy nauczyciel swoje odpowiedzi skonsultuje ze zdaniem innych nauczycieli, specjalistów i rodziców, stworzy to właściwą podstawę do napisania IPET-u.

Częstym błędem w tworzeniu IPET-ów jest zbyt drobiazgowy zapis zadań, który uniemożliwia elastyczne działanie. Trzeba pamiętać, że jeśli program ten ma być użyteczny w praktyce, musi być on raczej zwięzły, tak by nauczyciel mógł mieć go „w głowie” i kierować się jego założeniami we wszystkich swoich działaniach wo-

21 Rozporządzenie Ministra Edukacji Narodowej z dnia 9 sierpnia 2017 r. w sprawie warunków organizowania kształcenia... 
bec ucznia. Można mówić więc o stosunkowo ogólnych, choć specyficznych ze względu na indywidualny charakter programu dyrektywach oraz wiodących metodach i ich dostosowaniach, które łatwo zapamiętać i wdrażać każdego dnia, na każdej lekcji, w każdej sytuacji. Powinno się to przekładać także na stanowienie celów, które nie mogą być ani zbyt ogólne, ani zbyt odlegle, ani takie, które wymkną się okresowej ewaluacji (WOPFU). Lepiej zaplanować mniejsze kroki, aby mieć kontrolę nad ich wykonaniem, niż zbyt wielkie, ale nie dające możliwości uchwycenia dynamiki zmian. Warto poddać weryfikacji pod takim kątem cele formułowane na użytek IPET-u, by później łatwiej dokonać jego ewaluacji.

Na zakończenie trzeba podkreślić raz jeszcze, że dobry IPET nie będzie dokumentem dla osób kontrolujących szkołę/placówkę zamkniętym $w$ kolorowym segregatorze, ale narzędziem do dobrej codziennej pracy pedagogicznej. Pomoże $\mathrm{w}$ adaptacji procesu dydaktycznego, w przygotowaniu odpowiednich materiałów, a przede wszystkim pozwoli osiągnąć naszemu niepełnosprawnemu dziec$\mathrm{ku}$ /uczniowi sukces. Pomóżmy osiągać mu wiele sukcesów i sprawmy, aby był po prostu szczęśliwy. Warto pamiętać o tych prostych zasadach ukierunkowujących pracę pedagogiczną z uczniem ze SPE, podczas tworzenia wszelkiej dotyczącej go dokumentacji. Chodzi bowiem o to, by w formalnym podejściu do złożonych często dokumentów, nie zagubić samego dziecka.

\section{Zakończenie}

Przedstawiona $w$ artykule droga od orzeczenia do IPET-u nie jest łatwa, choć z pozoru taka się wydaje. Odebranie z publicznej Poradni Psychologiczno-Pedagogicznej druku orzeczenia, złożenie go w szkole lub placówce spowoduje konieczność napisania WOPFU i IPET-u. Najważniejsze dla pracy z uczniem jest stworzenie IPET-u tak, aby był on swoistym drogowskazem dla nauczycieli i specjalistów pracujących z podopiecznym. Cytowane przeze mnie przepisy prawa wskazują konieczność minimum dwukrotnych spo- 
tkań zespołu nauczycieli pracujących z uczniem posiadającym orzeczenie o potrzebie kształcenia specjalnego oraz konieczność zawiadomienia rodziców o terminie spotkania. Trzeba przemyśleć ich rolę w tworzeniu IPET-u. Współpraca z rodzicami może okazać się kluczem do sukcesu. Nauczyciele przedmiotów, którzy mają tylko jedną godzinę lekcyjną w tygodniu muszą uczestniczyć w pracach wielu zespołów. Szczególnie w mniejszych szkołach spotkania zespołów wymagają odpowiedniej logistyki. Generują również niechęć i zmęczenie nauczycieli, którzy muszą poświęcić na nie wiele dodatkowego czasu. Wysiłek włożony w dobre przygotowanie planu pracy z dzieckiem, w szczególności w trafną diagnozę funkcjonalną oraz planowanie pracy, powinien - dzięki wspólnym i przemyślanym działaniom - zapewnić optymalny rozwój ucznia, mimo istniejących ograniczeń. Jest to możliwe, choć wiele zadań dotyczących specjalnych potrzeb edukacyjnych na styku poradnia - szkoła/ przedszkole, bez odpowiedniej organizacji i wsparcia ciągle jeszcze niepotrzebnie rodzi wiele napięć i nieporozumień.

Mam nadzieję, że po lekturze tego artykułu droga do IPET-u okaże się nieco prostsza niż była do tej pory. Wskaże on pewne możliwości przeorganizowania pracy w szkołach/przedszkolach tak, aby wspieranie dzieci niepełnosprawnych w placówkach ogólnodostępnych, było o wiele bardziej praktyczne, celowe i właściwe.

\section{Bibliografia}

Chrzanowska I., Pedagogika specjalna. Od tradycji do wspótczesności. Impuls, Kraków 2015; Szumski G. Integracyjne kształcenie niepełnosprawnych, Wydawnictwo APS i PWN, Warszawa 2013.

Chrzanowska I., Strategia ksztatcenia osób niepetnosprawnych. Diagnoza pozoru, [w:] Człowiek z niepetnosprawnościa w rezerwacie przestrzeni publicznej, red. Z. Gajdzica, Oficyna Wydawnicza „Impuls”, Kraków 2013.

Cybulska R., Uczeń ze specjalnymi potrzebami edukacyjnymi w systemie edukacji w świetle nowych przepisów prawa oświatowego, Wydawnictwo Ośrodka Rozwoju Edukacji, Warszawa 2017.

Dudzińska A., Niedźwiedzka A., Najczęstsze pytania dotyczące ksztatcenia specjalnego informator dla rodziców, [online] http://niegrzecznedzieci.org.pl/wp-content/ 
uploads/2016/01/WszystkoJasne-Raport-Najcze\%CC\%A8stsze-Pytania-Dotycza\% CC\%A8ce-Kszta\%C5\%82cenia-Specjalnego.pdf [dostęp: 20.05.2017].

Jachimczak B., Special Pedagogue in a mainstream school - a possibilities and limitation, „Studia Edukacyjne” 2008, Nr 7.

Jachimczak B., Przygotowanie nauczycieli wychowania przedszkolnego do realizacji wybranych zadań z zakresu pomocy psychologiczno-pedagogicznej, "Studia Edukacyjne” 2013, Nr 21.

Plichta P., Przygotowanie nauczycieli do edukacji wtaczającej - kontekst europejski, [w:] Dobre praktyki pedagogiczne szansa innowacyjnej edukacji, D. Podgórska-Jachnik (red.), Wydawnictwo Wyższej Szkoły Pedagogicznej, Łódź 2012.

Podgórska-Jachnik D., Uwarunkowania i perspektywy edukacji włączającej osób z uszkodzonym stuchem, [w:] Edukacja niestyszacych, red. E. Twardowska, M. Kowalska, Polski Związek Głuchych w Łodzi, Łódź 2011.

Skibska I., Warchał M., Edukacja inkluzyjna dziecka niepetnosprawnego w szkole ogólnodostępnej a integracja społeczna, [w:] Edukacja Jutra w kontekście wyzwań wspótczesności, red. K. Denek i in., Oficyna Wydawnicza „Humanitas”, Sosnowiec 2011.

Rafał-Łuniewska J., Zmiany warunków organizowania ksztatcenia specjalnego, ORE Warszawa 2015: https://www.ore.edu.pl/component/phocadownload/catego ry/77-inne?download=3450:zmiany-warunkow-organizowania-ksztalcenia-spec jalnego-w-edukacji-ogolnodostepnej [dostęp: 10.06.2017].

Wykaz aktów prawnych

Rozporządzenie Ministra Edukacji Narodowej z dnia 24 lipca 2015 r. w sprawie warunków organizowania kształcenia, wychowania i opieki dla dzieci i młodzieży niepełnosprawnych, niedostosowanych społecznie i zagrożonych niedostosowaniem społecznym Dz.U. z dnia 7 sierpnia 2015 poz. 1113.

Rozporządzenie Ministra Edukacji Narodowej z dnia 9 sierpnia 2017 r. w sprawie warunków organizowania kształcenia, wychowania i opieki dla dzieci i młodzieży niepełnosprawnych, niedostosowanych społecznie i zagrożonych niedostosowaniem społecznym (Dz.U. z dnia 24 sierpnia 2017 r. poz. 1578).

Rozporządzenie Ministra Edukacji Narodowej z dnia 7 września 2017 r. w sprawie orzeczeń i opinii wydawanych przez zespoły orzekające działające w publicznych poradniach psychologiczno-pedagogicznych (Dz.U. 2017, poz. 1743). 